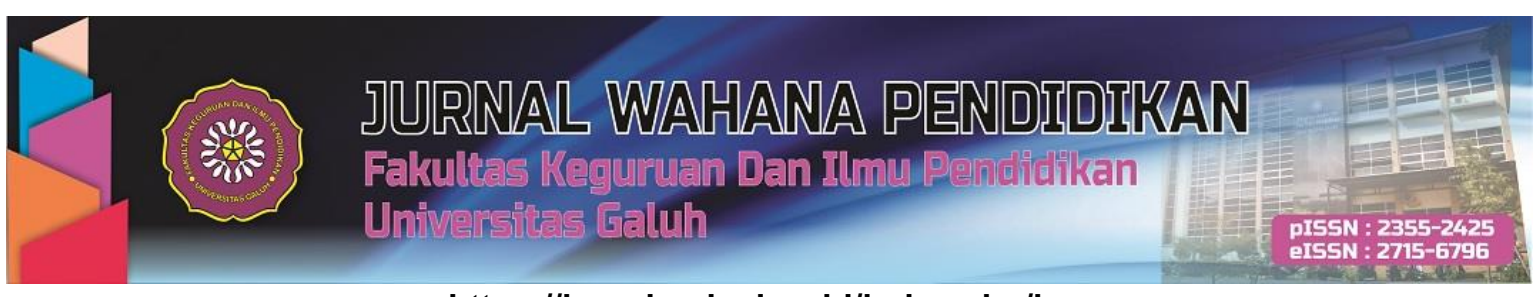

https://jurnal.unigal.ac.id/index.php/jwp

\title{
MENINGKATKAN KINERJA GURU DALAM PEMBELAJARAN MELALUI PEMBIMBINGAN INTENSIF SD NEGERI CIBANGBAY KOTA TASIKMALAYA
}

\author{
Dede Maryati ${ }^{1}$ \\ ${ }^{1}$ SDN Cibangbay, Jl. Sukasari Kel. Setiawargi Kecamatan Tamansari Tasikmalaya, Jawa Barat, Indonesia \\ Email: cibangbaysdn@gmail.com
}

\begin{abstract}
Education in schools is greatly influenced by the quality of its teaching staff and education. The purpose of this study is to describe the application of intensive guidance and inservice-training and upgrading activities in improving teacher teaching performance according to their main duties and functions as an effort to realize the vision and mission that has been formulated by SD Negeri Cibangbay Kota Tasikmalaya. This research is a school action research. The data used to support this research are the preparation of lesson preparation plans, implementation of teaching and learning activities, student learning evaluation results, observation sheets and teaching supervision sheets. This research was conducted using two cycles of school action research with four stages in each cycle, namely planning, acting, observing, and reflecting. The results of the first cycle of 16 teachers whose teaching performance was in the unsatisfactory category. This is not as expected. Therefore, the action was carried out in cycle II. The results of cycle II were 11 teachers, in other words $68.7 \%$ of teachers had very satisfying teaching abilities and $31.3 \%$ of teachers were in satisfactory categories. The results of this study indicate that intensive mentoring activities can improve teacher teaching performance.
\end{abstract}

\section{Keywords: Teacher performance, learning, intensive guidance}

\section{ABSTRAK}

Pendidikan di sekolah sangat dipengaruhi oleh kualitas tenaga pendidik dan kependidikannya. Tujuan dari penelitian ini adalah untuk mendeskripsikan penerapan pembimbingan intensif dan kegiatan inservice-training dan upgrading dalam meningkatkan kinerja mengajar guru sesuai tugas pokok dan fungsinya sebagai upaya mewujudkan visi dan misi yang sudah dirumuskan SD Negeri Cibangbay Kota Tasikmalaya. Penelitian ini merupakan penelitian tindakan sekolah. Data yang digunakan untuk mendukung penelitian ini adalah penyusunan Rencana Persiapan Pembelajaran, pelaksanaan Kegiatan Belajar Mengajar, hasil evaluasi belajar siswa, lembar observasi dan lembar supervisi pengajaran. Penelitian ini dilaksanakan dengan menggunakan penelitian tindakan sekolah sebanyak dua siklus dengan empat tahap dalam setiap siklusnya, yaitu perencanaan (planning), pelaksanaan tindakan (acting), pengamatan (observing), dan refleksi (reflecting). Hasil siklus I dari 16 orang guru kinerja mengajarnya termasuk kategori kurang memuaskan. Hal ini belum seperti yang diharapkan. Oleh karena itu dilakukan tindakan dalam siklus II. Hasil siklus II sebanyak 11 orang guru dengan kata lain $68,7 \%$ guru memiliki kemampuan mengajar sangat memuaskan dan sebanyak 5 orang guru atau $31,3 \%$ mengajar dengan kategori memuaskan. Hasil penelitian tersebut menunjukkan bahwa kegiatan pembimbingan intensif dapat meningkatkan kinerja mengajar guru.

Kata Kunci: Kinerja guru, pembelajaran, pembimbingan intersif

Cara sitasi: Maryati, D. (2020). Meningkatkan Kinerja Guru dalam Pembelajaran Melalui Pembimbingan Intensif di SD Negeri Cibangbay Kota Tasikmalaya. Jurnal Wahana Pendidikan, 8 (1), 69- 76. 


\section{PENDAHULUAN}

Pendidikan yang berkualitas merupakan salah satu unsur penentu terciptanya sumber daya manusia yang berkualitas. Pendidikan merupakan faktor utama dalam pembentukan pribadi manusia (Arifin, 2018: 251). Oleh karena itu peningkatan mutu pendidikan menjadi salah satu kebijakan dari Departemen Pendidikan dan Kebudayaan Republik Indonesia. Salah satu upaya untuk meningkatkan mutu pendidikan adalah dengan meningkatkan kualitas guru dalam proses pembelajaran. Guru merupakan ujung tombak keberhasilan pendidikan. Tidak bisa dipungkiri, bahwa guru merupakan salah satu unsur pendidikan dimana peranannya sangat dominan dalam peningkatan mutu pendidikan.

Guru merupakan elemen kunci dalam sistem pendidikan, khususnya di sekolah. Hal ini disebabkan karena guru merupakan titik sentral dalam pembaharuan dan peningkatan mutu pendidikan, dengan kata lain salah satu persyaratan penting bagi terwujudnya pendidikan yang bermutu adalah apabila pelaksanaannya dilakukan oleh pendidik-pendidik yang keprofesionalannya dapat diandalkan. Guru sebagai pemimpin memberikan materi pelajaran dan sekaligus sebagai pendidik agar anak pintar dan juga berakhlak mulia (terpuji) Heriyansyah (2018: 119).

Profesionalisme merupakan hal penting dimiliki oleh setiap guru madrasah karena menjadi kunci sukses dalam menjalankan profesi keguruannya di dunia pendidika (Tambak dan Sukenti, 2020: 42). Lebih lanjut, Anshori (2020: 54) menjelaskan: "Keahlian (Skill) yang dimiliki guru profesional diperoleh melalui proses pendidikan dan pelatihan yang diikuti guru yang telah diprogramkan secara khusus". Tinggi rendahnya mutu hasil belajar siswa banyak tergantung pada kemampuan mengajar guru. Apbila guru memiliki kemampuan mengajar yang baik, maka akan membawa dampak peningkatan iklim belajar mengajar yang baik. Hal ini dikarenakan guru terlibat langsung dalam proses pembelajaran di sekolah. Agar proses pembelajaran bisa berjalan dengan aktif, inovatif, kreatif, efektif dan menyenangkan, maka guru-gurunya pun harus berkualitas dan profesional.

Guru yang profesional adalah guru yang memiliki kemampuan dan keahlian khusus dalam bidang keguruan, sehingga ia mampu melaksanakan tugas pokok dan fungsinya sebagai guru dengan maksimal. Profesionalisme seorang guru terlihat dari kompetensinya sebagai seorang guru. Guru profesional dituntut memiliki kompetensi guru seperti yang dituangkan dalam Undang-undang Nomor 14 Tahun 2005 tentang Guru dan Dosen yaitu terdiri dari kompetensi kepribadian, pedagogik, profesional dan kompetensi sosial. Salah satu dimensi kompetensi guru sesuai dengan undangundang tersebut adalah kompetensi profesional, berarti seorang guru harus kompeten dalam melakukan kinerja profesionalnya.

Upaya profesionalisasi guru dalam bentuk in-service telah banyak dilakukan, baik oleh pemerintah maupun oleh badan independen yang peduli pada peningkatan mutu pendidikan. Tenaga kependidikan berkewajiban untuk berusaha mengembangkan kemampuan profesioanalnya sesuai dengan tuntutan perkembangan ilmu pengetahuan dan teknologi serta pembangunan bangsa (Mustofa, 2007). Berkaitan dengan hal tersebut di atas, maka kepala sekolah selaku manager, supervisor, dan fasilitator sangat perlu untuk melaksanakan pembimbingan intensif dari hasil inservice-training dan upgrading bagi guru-guru. Kepala sekolah harus memfasilitasi guru-guru dalam kegiatan yang dapat menunjang kemampuan mengajar. Kegiatan tersebut antara lain workshop, seminar, Kelompok Kerja Guru (KKG), kursus, survei masyarakat dan sebagainya. Selain itu kepala sekolah perlu melakukan pembimbingan secara intensif terhadap guru di tingkat sekolah untuk meningkatkan kinerjanya (Turmiyati, 2017).

Berdasarkan hasil observasi guru-guru di SD Negeri Cibangbay masih kurang optimal dalam melaksanakan tugasnya. Hal ini terjadi karena kurang maksimalnya ketersediaan sarana dan prasarana yang menunjang proses pembelajaran seperti buku siswa, buku guru serta alat peraga pembelajaran. Faktor lain yang menyebabkan kurang optimalnya guru dalam mengajar adalah keterbatasan kemampuan guru di bidang ilmu pengetahuan dan teknologi, sehingga kesulitan mengikuti kemajuan teknologi dan melakukan inovasi. Sebanyak 50\% guru dari total 16 orang guru 
belum bisa mengoperasikan laptop, sehingga melaksanakan proses pembelajaran secara konvensional. Siswa cenderung pasif, duduk, dengar dan catat apa yang diajarkan guru. Guru masih kurang dalam melakukan persiapan pembelajaran, sehingga situasi kelas monoton.

Kualifikasi pendidikan juga menjadi salah satu faktor penyebab kurang maksimalnya kinerja guru dalam proses pembelajaran. Masih ada guru yang belum menempuh pendidikan $\$ 1$. Walaupun kepala sekolah sudah berkali-kali mendorong dan memotivasi untuk kuliah. Namun sampai saat ini belum terealisasi karena berbagai alasan. Kurang optimalnya kinerja guru dalam melaksanakan pembelajaran berpengaruh terhadap hasil belajar siswa dan kualitas lulusan. Dari uraian di atas, maka dipandang perlu dilakukan upaya peningkatan kemampuan kinerja guru dalam mengajar melalui pembimbingan intensif.

Berdasarkan latar belakang tersebut maka tujuan penelitian ini adalah untuk mendeskripsikan penerapan pembimbingan intensif dalam meningkatkan kinerja mengajar guru sesuai tugas pokok dan fungsinya, sebagai upaya mewujudkan pendidikan yang berkualitas sesuai dengan visi SD Negeri Cibangbay yaitu "Mewujudkan sekolah yang unggul, kompetitif dengan dilandasi akhlak mulia".

\section{METODE PENELITIAN}

Metode penelitian pada dasarnya merupakan cara ilmiah untuk mendapatkan data dengan tujuan dan kegunaan tertentu (Sugiyono, 2016:2). Metode yang digunakan dalam penelitian ini adalah penelitian tindakan sekolah. Penelitian ini dilaksanakan di SD Negeri Cibangbay Kota Tasikmalaya selama empat bulan yaitu pada bulan Januari sampai bulan April 2019 (semester 2 tahun pelajaran 2019/2020). Subyek penelitian adalah guru-guru di SD Negeri Cibangbay Kota Tasikmalaya yang berjumlah 16 orang. Dari 16 orang guru yang menjadi subyek penelitian ini mempunyai karakter dan latar belakang yang berbeda. 14 orang guru mempunyai latar pendidikan Strata 1 (S1), dan 2 orang guru dengan latar belakang pendidikan D2. Dari 14 guru tersebut latar belakang pendidikannya $\mathrm{S} 1$ jurusan yang berbeda.

Jenis data yang dikumpulkan pada penelitian ini adalah data kualitatif dan data kuantitatif. Instrumen yang digunakan dalam penelitian ini terdiri atas: a) lembar angket, (b) pelaksanaan pembelajaran, (c) evaluasi hasil siswa, (d) lembar observasi, (e) hasil supervisi, dan (f) sertifikat yang dimiliki guru. Penelitian ini dilaksanakan dengan menggunakan penelitian tindakan sekolah sebanyak dua siklus. Adapun langkah-langkah dari penelitian ini dijabarkan sebagai berikut.

\section{a. Siklus Pertama.}

Siklus pertama ini dilaksanakan melalui empat tahap, yaitu 1) perencanaan (planning), 2) pelaksanaan tindakan (acting), 3) pengamatan (observasing), dan 4) refleksi (reflecting). Kegiatan pada tahap perencanaan antara lain: a) menyusun lembar observasi yang akan digunakan dalam pengamatan pada saat proses belajar mengajar, (b)menyusun daftar pertanyaan yang harus diisi oleh guru setelah dilakukan observasi, (c)merumuskan dan membuat format penilaian untuk mengetahui tingkat penguasaan kompetensi yang dimiliki oleh guru, (d)membuat jadwal kunjungan atau supervisi pengajaran di masing-masing kelas.

Tahap selanjutnya kegiatan pelaksanaan (acting) adalah kegiatan untuk melaksanakaan rencana program yang telah disusun sebelumnya. Kegiatan yang dilakukan antara lain: 1) melaksanakan supervisi pengajaran di kelas I sampai kelas VI, 2) mengamati guru kelas I sampai guru kelas VI pada saat mengajar, 3) mencocokkan antara rencana pelaksanaan pembelajaran yang disusun dengan praktik mengajarnya, 4) mencatat temuan-temuan pada saat pembelajaran yang akan dijadikan masukan dan saran kepada guru dalam pelaksanaan kegiatan pembelajaran berikutnya, 5) bersama dengan guru mencari solusi tentang permasalahan yang menjadi kendala guru pada saat mengajar.

Pada tahap pengamatan dilakukan observasi untuk pencatatan hasil supervisi pengajaran dan kemudian dihubungkan dengan kondisi yang terjadi pada saat berlangsungnya tindakan terutama meliputi kemampuan guru dalam melaksanakan tugas pembelajaran dan respon siswa yang 
ditunjukan dengan hasil evaluasi di akhir kegiatan belajar mengajar. Rekaman data yang diperoleh pada tahap observasi diolah pada tahap ini. Hasil olah data digunakan sebagai acuan refleksi yang kemudian menjadi dasar penyusunan rencana kegiatan atau tindakan pada siklus berikutnya.

\section{b. Siklus Kedua.}

Perencanaan pada siklus kedua ini disusun berdasarkan hasil observasi dan refleksi siklus pertama. Hal ini dimaksudkan agar hasil pembelajaran pada siklus yang kedua mengalami peningkatan. Kelemahan-kelemahan yang ditemukan pada siklus pertama diatasi pada siklus kedua, terutama pada tahap pelaksanaan tindakan. Bersamaan dengan itu dilakukan observasi. Kemudian dilanjutkan dengan tahap refleksi. Perencanaan siklus yang kedua ini hampir sama dengan siklus pertama. Bedanya pada tahap kedua tidak ada diagnosis awal karena data sudah diperoleh dari refleksi siklus pertama. Sedangkan kegiatan lain ditujukan untuk mengatasi hambatan yang ditemukan pada siklus pertama. Dengan demikian kemampuan guru dalam mengajar akan mengalami peningkatan. Jika kemampuan kinerja guru meningkat, diharapkan prestasi belajar siswa akan meningkat pula seperti harapan orang tua.

Data-data yang didapatkan baik pada siklus I maupun siklus II direkam dan dianalisis. Indikator keberhasilan dalam Penelitian Tindakan Sekolah (PTS) ini adalah jika $80 \%$ jumlah guru yang ada di SD Negeri Cibangbay mempunyai kemampuan yang baik dalam proses pembelajaran. Sebagai tolak ukur keberhasilan guru dalam mengajar apabila masuk dalam kategori memuaskan. Keberhasilan ini akan dilihat dari beberapa aspek antara lain aspek administrasi dalam membuat rencana pelaksanaan pembelajaran (RPP), penampilan dalam praktik pembelajaran, evaluasi hasil belajar siswa. Adapun acuan kriteria keberhasilan secara lengkap seperti dalam Tabel 1 berikut.

Tabel 1

Kategori Kemampuan Guru

\begin{tabular}{cc}
\hline Rentang Nilai & Kategori \\
\hline $3,50-4,00$ & Sangat Memuaskan \\
$3,00-3,49$ & Memuaskan \\
$2,50-2,99$ & Kurang Memuaskan \\
\hline
\end{tabular}

\section{HASIL DAN PEMBAHASAN}

Kurikulum yang digunakan di SD Negeri Cibangbay adalah Kurikulum 2013. Berdasarkan hasil pengisian angket yang dilakukan oleh guru kelas diketahui bahwa sebagian besar guru dalam proses pembelajaran menunjukan kemampuan yang masih rendah. Melihat kenyataan tersebut maka penulis mencoba untuk mengatasi masalah tersebut dengan melaksanakan supervisi pengajaran. Setelah pelaksanaan supervisi pengajaran dan pembimbingan secara intensif serta penyegaran kembali kepemilikan sertifikat seminar atau sejenisnya ternyata menunjukkan peningkatan. Berikut kondisi awal kemampuan guru dalam mengajar sebelum dilaksanakan supervisi pengajaran seperti pada Tabel 2.

Tabel 2

Rekapitulasi Hasil Observasi Kemampuan Guru Pra Siklus

\begin{tabular}{cccccccc}
\hline Kode Guru & 1 & 2 & 3 & 4 & 5 & 6 & Rata-rata \\
\hline 1 & 2,5 & 2,5 & 2,5 & 2,5 & 2,5 & 2,5 & 2,5 \\
2 & 2,3 & 2,3 & 2,5 & 2,3 & 2,5 & 2,5 & 2,4 \\
3 & 2,5 & 2,5 & 2,3 & 2,5 & 2.5 & 2,3 & 2,43 \\
4 & 2,3 & 2,5 & 2,3 & 2,5 & 2,5 & 2,3 & 2,4 \\
5 & 2,5 & 2,5 & 2,5 & 2,5 & 2,5 & 2,5 & 2,5 \\
6 & 2,5 & 2,5 & 2,5 & 2,5 & 2,5 & 2,5 & 2,5 \\
7 & 2,4 & 2,3 & 2,5 & 2,5 & 2,5 & 2,5 & 2,4 \\
8 & 2,3 & 2,5 & 2,5 & 2,3 & 2,3 & 2,3 & 2,43 \\
9 & 2,1 & 2,3 & 2,5 & 2,5 & 2,5 & 2,5 & 2,4 \\
10 & 2,3 & 2,5 & 2,3 & 2,5 & 2,3 & 2,5 & 2,5 \\
11 & 2,1 & 2,5 & 2,5 & 2,4 & 2,5 & 2,4 & 2,4 \\
12 & 2,4 & 2,4 & 2,3 & 2,3 & 2,5 & 2,3 & 2,43 \\
13 & 2,3 & 2,3 & 2,5 & 2,5 & 2,4 & 2,5 & 2,4 \\
14 & 2,5 & 2,5 & 2,5 & 2,3 & 2,3 & 2,3 & 2,5
\end{tabular}




\begin{tabular}{cccccccc}
\hline 15 & 2,4 & 2,3 & 2,4 & 2,5 & 2,5 & 2,5 & 2,4 \\
16 & 2,3 & 2,5 & 2,3 & 2,3 & 2,3 & 2,5 & 2,43 \\
\hline
\end{tabular}

\section{a. Siklus I}

Dari hasil pembimbingan intensif yang dilakukan siklus pertama dapat dilihat adanya peningkatan kinerja guru dalam mengajar, meskipun peningkatan tersebut belum optimal. Hasil rekapitulasi penilaian kinerja guru setelah siklus I seperti pada Tabel 3. berikut

\section{Tabel 3}

Hasil Rekapitulasi Pengamatan Kinerja Guru Siklus I

\begin{tabular}{cccccccc}
\hline Subjek & $\mathbf{1}$ & $\mathbf{2}$ & $\mathbf{3}$ & $\mathbf{4}$ & $\mathbf{5}$ & $\mathbf{6}$ & Rata-rata \\
\hline 1 & 2,5 & 3 & 3 & 2,5 & 3 & 3 & 2,83 \\
2 & 2,5 & 2,5 & 3 & 2,5 & 2,5 & 3 & 2,67 \\
3 & 2,5 & 3 & 3 & 2,5 & 2,5 & 3 & 2,75 \\
4 & 2,5 & 2,5 & 2,5 & 3 & 2,5 & 3 & 2,67 \\
5 & 2,5 & 2,5 & 3 & 2,5 & 3 & 3 & 2,75 \\
6 & 2,5 & 2,5 & 3 & 3 & 3 & 3 & 2,83 \\
7 & 2,4 & 3 & 3 & 3 & 3 & 2,5 & 2,83 \\
8 & 2,4 & 2,5 & 2,5 & 2,5 & 3 & 3 & 2,67 \\
9 & 2,3 & 2,5 & 2,5 & 3 & 3 & 3 & 2,75 \\
10 & 2,3 & 2,5 & 2,5 & 2,5 & 3 & 3 & 2,67 \\
11 & 2,5 & 3 & 3 & 3 & 2,5 & 2,5 & 2,75 \\
12 & 2,5 & 2,5 & 3 & 3 & 3 & 3 & 2,83 \\
13 & 2,5 & 2,5 & 2,5 & 2,5 & 3 & 3 & 2,67 \\
14 & 2,5 & 2,5 & 3 & 2,5 & 3 & 3 & 2,75 \\
15 & 3 & 3 & 2,5 & 2,5 & 2,5 & 2,5 & 2,67 \\
16 & 2,4 & 2,5 & 2,5 & 3 & 3 & 3 & 2,75
\end{tabular}

Setelah pelaksanaan supervisi kelas pada siklus pertama dicatat hasil kemampuan guru dalam pembelajaran dari 16 orang guru sudah mengalami peningkatan kemampuan dalam mengajar, namun belum sesuai harapan karena kemampuan guru tersebut dalam mengajar masih termasuk kategori kurang memuaskan. Meskipun demikian penulis menghargai usaha yang telah dilakukannya dan tetap optimis bahwa jika usaha kita lakukan terus menerus maka akan lebih baik lagi. Kepala Sekolah kemudian memberi pembimbingan secara intensif dan membantu memecahkan kesulitan yang yang dialami guru.

Dari hasil supervisi kelas siklus pertama menjadi acuan untuk melakukan kegiatan siklus yang kedua. Pada kegiatan refleksi hasil siklus 1 ini penulis melakukan kegiatan sebagai berikut: 1) melakukan diskusi dengan para guru yang telah disupervisi oleh penulis, 2). menyampaikan temuantemuan terutama kekurangan atau kelemahan guru pada saat melaksanakan proses pembelajaran, 3) mencari solusi dan memberikan arahan serta bimbingan secara intensif atas temuan-temuan yang diperloleh penulis selama melakukan supervisi pengajaran, 4) menyusun rencana program untuk melaksanakan kegiatan siklus yang kedua.

\section{b. Siklus II}

Berdasarkan hasil refleksi pada siklus pertama dijadikan acuan untuk membuat perencanaan tindakan pada siklus yang kedua. Setelah melakukan diskusi dan pembimbingan intensif dengan guru yang disupervisi, kegiatan yang dilakukan pada siklus II disepakati jadwal supervisi kelas untuk siklus yang kedua, melaksanakan supervisi pengajaran dari masing-masing kelas, kemudian mengamati dan mencatat hasil supervisi pengajaran. Hasil rekapitulasi penilaian kinerja guru setelah siklus II seperti pada Tabel 4. 
Tabel 4

Hasil Rekapitulasi Pengamatan Kinerja Guru Siklus II

\begin{tabular}{cccccccc}
\hline $\begin{array}{c}\text { Subjek } \\
\text { guru }\end{array}$ & 1 & 2 & 3 & 4 & 5 & 6 & Rata-rata \\
\hline 1 & 3,5 & 3,5 & 4 & 3,5 & 3,5 & 4 & 3,67 \\
2 & 3 & 3,5 & 3,5 & 3,5 & 3,5 & 3,5 & 3,42 \\
3 & 3,5 & 3,5 & 3 & 3,5 & 3,5 & 4 & 3,5 \\
4 & 3 & 3,5 & 3 & 3,5 & 3,5 & 3,5 & 3,33 \\
5 & 3 & 3,5 & 3,5 & 3,5 & 3,5 & 4 & 3,5 \\
6 & 3,5 & 3,5 & 3 & 3,5 & 3,5 & 4 & 3,5 \\
7 & 3 & 3,5 & 3,5 & 3,5 & 3,5 & 3,5 & 3,42 \\
8 & 3,5 & 3,5 & 3 & 3 & 3,5 & 4 & 3,5 \\
9 & 3 & 3,5 & 3 & 3 & 3,5 & 3,5 & 3,33 \\
10 & 3 & 3,5 & 3,5 & 3,5 & 3,5 & 4 & 3,5 \\
11 & 3,5 & 3,5 & 3 & 3 & 3,5 & 4 & 3,5 \\
12 & 3 & 3,5 & 3 & 3,5 & 3,5 & 4 & 3,5 \\
13 & 3,5 & 3,5 & 3 & 3 & 3,5 & 4 & 3,5 \\
14 & 3 & 3,5 & 3 & 3 & 3,5 & 3,5 & 3,33 \\
15 & 3 & 3,5 & 3,5 & 3,5 & 3,5 & 4 & 3,5 \\
16 & 3,5 & 3,5 & 3 & 3 & 3,5 & 4 & 3,5 \\
& & & & & & & \\
\hline
\end{tabular}

Pada siklus kedua, setelah diadakan pembimbingan intensif pada tahap ini menunjukan hasil peningkatan kemampuan kinerja guru dalam mengajar yang sangat signifikan. Berdasarkan hasil siklus kedua dari 16 orang guru yang diamati oleh penulis menunjukkan hasil sebanyak 11 orang guru dengan kata lain 68,7\% guru memiliki kemampuan mengajar sangat memuaskan dan sebanyak 5 orang guru atau 31,3\% mengajar dengan kategori memuaskan. Berdasarkan hasil tersebut sudah memenuhi kriteria keberhasilan tindakan yang dilakukan sehingga tidak dilakukan lagi siklus berikutnya. Dari hasil siklus kedua penulis mencatat temuan-temuan pada saat supervisi pengajaran yang kedua dan hasil temuan itu dapat digunakan sebagai acuan perbaikan dalam proses pembelajaran dalam penyelenggaraan pembelajaran selanjutnya.

Peningkatan kemampuan mengajar guru selama dilakukanya penelitian tindakan ini dapat dilihat dalam tabel 5 berikut.

Tabel 5

Perbandingan dan Peningkatan Antar Siklus

\begin{tabular}{cccc}
\hline Subjek Guru & Prasiklus & Siklus 1 & Siklus 2 \\
\hline 1 & 2,5 & 2,83 & 3,67 \\
2 & 2,4 & 2,67 & 3,42 \\
3 & 2,43 & 2,75 & 3,5 \\
4 & 2,4 & 2,67 & 3,33 \\
5 & 2,5 & 2,75 & 3,5 \\
6 & 2,5 & 2,83 & 3,5 \\
7 & 2,4 & 2,83 & 3,42 \\
8 & 2,43 & 2,67 & 3,5 \\
9 & 2,4 & 2,75 & 3,33 \\
10 & 2,5 & 2,67 & 3,5 \\
11 & 2,4 & 2,75 & 3,5 \\
12 & 2,43 & 2,83 & 3,5 \\
13 & 2,4 & 2,67 & 3,5 \\
14 & 2,5 & 2,75 & 3,33 \\
15 & 2,4 & 2,67 & 3,5 \\
16 & 2,43 & 2,75 & 3,5 \\
Rata-rata & 2,44 & $\mathbf{2 , 7 4}$ & 3,47 \\
\hline
\end{tabular}

Dari analisis data dapat kita ketahui bahwa kemampuan kinerja guru dalam mengajar mengalami peningkatan rata-rata kemampuan kinerja guru dalam tiap siklus setelah dilakukan 
kegiatan pembimbingan intensif. Hal ini terlihat dari cara mengajar guru dan hasil belajar yang dicapai siswa. Hasil penelitian ini sejalan dengan hasil penelitian Sulastri (2020) menyatakan melalui supervisi akademik dengan bimbingan intensif secara kelompok dan individu dapat meningkatkan kompetensi guru pada indikator tarap serap kemampuan menyusun RPP berbasis tuntas dan kemampuan melaksanakan pembelajaran berbasis tuntas. Hal ini sesuai dengan pandangan ahli bahwa bimbingan dapat diberikan pada individu dari berbagai jenjang usia untuk mengembangkan kepribadian serta pandangan hidup baik secara individual maupun kelompok (Purwanto, 2003).

Perbaikan yang dilakukan untuk terus meningkatkan kemampuan guru dalam mengajar tentunya tidak berhenti sampai di sini. Kepala Sekolah terus menghimbau, membimbing dan membina para guru untuk terus melakukan inovasi perubahan dalam mengajar agar dapat meningkatkan hasil prestasi belajar siswa. Dengan demikian akan meningkat mutu pendidikan di SD Negeri Cibangbay Kota Tasikmalaya.

\section{KESIMPULAN}

Hasil siklus I dari 16 orang guru kinerja mengajarnya termasuk kategori kurang memuaskan. Hal ini belum seperti yang diharapkan. Oleh karena itu dilakukan tindakan dalam siklus II. Hasil siklus II sebanyak 11 orang guru dengan kata lain $68,7 \%$ guru memiliki kemampuan mengajar sangat memuaskan dan sebanyak 5 orang guru atau $31,3 \%$ mengajar dengan kategori memuaskan. Hasil penelitian tersebut menunjukkan bahwa kegiatan pembimbingan intensif dapat meningkatkan kinerja mengajar guru-guru di SD Negeri Cibangbay Kota Tasikmalaya Tahun Pelajaran 2019/2020.

\section{REKOMENDASI}

Hasil Penelitian pada siklus II masih terdapat beberapa catatan yang memerlukan perbaikan pada saat pelaksaan tindakan pembimbingan intensif pada guru-guru. Kepala Sekolah terus menghimbau, membimbing dan membina para guru untuk terus melakukan inovasi perubahan dalam mengajar agar dapat meningkatkan hasil prestasi belajar siswa. Kepala sekolah dapat melakukan kegiatan supervisi akademik secara periodik dan melakukan berbagai teknik pembimbingan yang bervariasi sehingga hasilnya dapat lebih maksimal.

\section{UCAPAN TERIMAKASIH}

Pada kesempatan ini penulis menyampaikan terimakasih kepada siswa-siswa, guru-guru dan tenaga kependidikan di SD Negeri Cibangbay Kota Tasikmalaya yang telah berpartisipasi dan memberikan dukungan selama kegiatan penelitian ini dilaksanakan.

\section{DAFTAR PUSTAKA}

Anshori, Suryamah. (2020). Upaya Meningkatkan Disiplin Guru melalui Pemberian Reward dan Punishment di SDN 3 Wonoharjo Tahun Ajaran 2018/2019. Jurnal Wahana Pendidikan Volume 7 Nomor 1 Januari 2020.

Arifin, Nur Rizqi. (2018). Pengaruh Model Pembelajaran Kooperatif Tipe Student Team Achievement Division (STAD) terhadap Kemampuan Berpikir Kritis Siswa (Studi Eksperimen pada Mata Pelajaran Ekonomi Kelas XI SMA Informatika Ciamis). Jurnal Edukasi (Ekonomi, Pendidikan dan Akuntansi) Volume 6 Nomor 1 Juni 2018.

Heriyansyah. (2018). Guru Adalah Manajer Sesungguhnya Di Sekolah. Jurnal Manajemen Pendidikan Islam, Volume 1, Nomor 1, Januari 2018.

Mustofa. (2007). Upaya Pengembangan Profesionalisme Guru Di Indonesia. Jurnal Ekonomi \& Pendidikan, Volume 4 (1), p.76-88. 
Purwanto, M. N. (2003). Psikologi Pendidikan. Bandung: Remaja Rosdakarya

Sugiyono. (2016). Metode Penelitian Kuantitatif, Kualitatif dan R\&D. Bandung: PT Alfabeta.

Sulastri.2020. Supervisi Akademik Melalui Bimbingan Intensif Untuk Meningkatkan Kemampuan Guru Dalam Pembelajaran Tuntas. Jurnal Pro Guru, Vol 6 (4), p 404-409.

Tambak, Syahraini \& Desi Sukenti. (2020). Pengembangan Profesionalisme Guru Madrasah dengan Penguatan Konsep Khalifah. Hayula: Indonesian Journal of Multidisciplinary Islamic Studies, Volume 4, Nomor 1, Januari 2020.

Turmiyati, T . (2017). Pengaruh Kepemimpinan Kepala Sekolah Terhadap Motivasi Kerja Guru Di MTs Al-Hikmah Kedaton Bandar Lampung. Undergraduate thesis, IAIN Raden Intan Lampung.

Undang-undang Republik Indonesia Nomor 14 Tahun 2005 tentang Guru dan Dosen. 